\title{
ЗАБЕЗПЕЧЕННЯ ЕФЕКТИВНОГО КОРИГУВАЛЬНОГО ЗВОРОТНОГО ЗВ'ЯЗКУ МІЖ ВИКЛАДАЧЕМ ТА СТУДЕНТОМ У ПРОЦЕСІ ВИВЧЕННЯ ІНОЗЕМНОӦ МОВИ
}

У статmі розкрито проблему забезпечення ефективного коригувального зворотного зв'язку, як одного із видів зворотного зв'язку між викладачем та студентом у процесі вивчення іноземної мови у вищому закладі освіти. У даному дослідженні коригувальний зворотний зв'язок розглядається як спосіб корекції помилок студента на етапі контролю знань, умінь та навичок. Визначено фрункції зворотного зв'язку. Проаналізовано механізм та етапи здійснення зворотного зв'язку, розкрито його аспекти. У роботі докладно схарактеризовано усний та письмовий коригувальний зворотний зв'язок. Виокремлено види усного - експліцитний (прямий), металінгвістичний, імпліцитний (непрямий) та письмового коригувального зворотного зв'язку - прямий та непрямий. Підвиди непрямого усного коригувального зворотного зв'язку (перефразування висловлення, запит уточнення, домагання правильної відповіді й повторення з наголосом на помилці) схарактеризовано з погляду їхніх особливостей, відмінностей та ефрективності їх використання. Проаналізовано підхід до виправлення помилок студента в письмовій роботі та в усному мовленні. У роботі акцентовано увагу на умовах ефрективного забезпечення коригувального зворотного зв'язку. З'ясовано, що для того, щоб зворотний зв'язок був ефрективним, слід дотримуватися послідовності в його організації, поєднувати різні види, ураховувати рівень засвоєння матеріалу студентами, їхню реакцію, розуміння його необхідності та обговорювати помилки зі студентами. Здійснення коригувального зворотного зв'язку розглянуто в різних формах навчання: очній та дистанційній. Визначено перспективи подальших досліджень, які мають бути спрямовані на науково обгрунтований аналіз та добір ефрективних прийомів, методів та засобів здійснення коригувального зворотного зв'язкуна різних етапах практичного заняття, у різних формах та видах роботи, а також у розрізі інноваційних технологій навчання, які викладач іноземної мови зможе використовувати в практичній діяльності.

Ключові слова: зворотний зв'язок; коригувальний зворотний зв'язок; зворотний зв'язок між викладачем та студентом; експліцитний зворотний зв'язок; імпліцитний зворотний зв'язок; процес вивчення іноземної мови.

Филипская Вита Ивановна, кандидат педагогических наук, старший преподаватель кафедры иностранных языков, Харьковский национальный университет внутренних дел, sch34_fylypska@ukr.net

\section{ОБЕСПЕЧЕНИЕ ЭФФЕКТИВНОЙ КОРРЕКТИРУЮЩЕЙ ОБРАТНОЙ СВЯЗИ МЕЖДУ ПРЕПОДАВАТЕЛЕМ И СТУДЕНТОМ В ПРОЦЕССЕ ИЗУЧЕНИЯ ИНОСТРАННОГО ЯЗЫКА}

В статье раскрыто проблему обеспечения эффрективной корректирующей обратной связи, как один из видов обратной связи между преподавателем и студентом в процессе изучения иностранного языка в высшем учебном заведении. В данном исследовании корректирующая обратная связь рассматривается как способ коррекции ошибок студента на этапе контроля знаний, умений и навыков. Определены фрункции обратной связи. Проанализирован механизм и этапы осуществления обратной связи, раскрыты его аспекты. В работе подробно охарактеризована устная и письменная корректирующая обратная связь. Выделены виды устной - эксплицитная (прямая), металингвистическая, имплицитная (непрямая) и письменная корректирующая обратная связи - прямая и непрямая. Подвиды непрямой устной корректирующей обратной связи (перефразирование высказывания, запрос уточнения, требование правильного ответа и повторения с ударением на ошибке) охарактеризованы с точки зрения их особенностей, различий и эфффективности использования. Проанализирован подход к исправлению ошибок студента в письменной работе и в устной речи. В работе акцентировано внимание на условиях эфрфективного обеспечения корректирующей обратной связи. Выяснено, что для того, чтобы обратная связь была эффрективной, следует соблюдать последовательность в ее организации, сочетать разные виды, учитывать уровень усвоения материала студентами, их реакцию, понимание ее необходимости и обсуждать ошибки со студентами. Осуществление корректирующей обратной связи рассмотрено в различных фрормах обучения: очной и дистанционной. Определены перспективы дальнейших исследований, которые должны быть направлены на научно обоснованный анализ и отбор эфорективных приемов, методов и средств осуществления корректирующей обратной связи на различных этапах практического занятия, в разных формах и видах работы, а также в разрезе инновационных технологий обучения, которые преподаватель иностранного языка сможет использовать в практической деятельности.

Ключевые слова: обратная связь; корректирующая обратная связь; обратная связь между преподавателем и студентом; эксплицитная обратная связь; имплицитная обратная связь; процесс изучения иностранного языка.

Fylypska, Vita, $\mathrm{PhD}$ in Pedagogical Sciences, Senior Lecturer of the Foreign Languages Department, Kharkiv National University of Internal Affairs, sch34_fylypska@ukr.net

PROVIDING EFFECTIVE CORRECTIVE FEEDBACK BETWEEN A TEACHER AND A STUDENT IN PROCESS OF FOREIGN LANGUAGE LEARNING

The article reveals the problem of providing effective corrective feedback as one of the types of feedback between a teacher 
and a student in the process of learning a foreign language in higher education. In this study, corrective feedback is considered as a way to correct student errors at the stage of knowledge control, skills and abilities. The functions of feedback are defined. The mechanism and stages of feedback implementation are analyzed, its aspects are revealed. The paper describes in detail the oral and written corrective feedback. The types of oral - explicit (direct), metalinguistic, implicit (indirect) and written corrective feedback - direct and indirect are distinguished. Subtypes of indirect oral corrective feedback (paraphrasing the statement, requesting clarification, seeking the correct answer and repetition with an emphasis on an error) are characterized in terms of their features, differences and efficiency of use. The approach of correcting student's mistakes in written work and oral speech is analyzed. The paper focuses on the conditions of effective provision of corrective feedback. It was found that in order for feedback to be effective, it is necessary to follow the sequence in its organization, combine different types, take into account the level of assimilation of the material by students, their reaction, understanding of its need and discussing mistakes with students. The implementation of corrective feedback is considered in various forms of training: face-to-face and distance. Prospects for further research to be aimed at scientifically sound analysis and selection of effective techniques, methods and means of corrective feedback at different stages of practical training, in different forms and types of work, as well as in terms of innovative learning technologies, which the teacher of foreign language can use in practice.

Keywords: feedback; corrective feedback; feedback between teacher and student; explicit feedback; implicit feedback; the process of learning a foreign language.

Постановка проблеми. У зв'язку з реалізацією в Україні Болонського процесу сучасне оновлення змісту і структури освіти вимагає докорінного перегляду стосунків між викладачем та студентом, зокрема перепрофілювання викладача з керівника навчальної діяльності, який має контролювати процес засвоєння знань студентами, в рівноправного учасника цього процесу (Вінниченко, 2012).

Для того щоб почуватися впевнено в цій ролі, викладачеві треба бути добре обізнаним з методами і технологією такого навчання, апробувати й відчути iii на власному досвіді. Створення сприятливого навчального середовища неможливе без здійснення зворотного зв'язку, який дозволяє викладачеві регулярно контролювати та коригувати процес отримання знань студентами (Божук, \& Малик, 2010).

Тому сьогодні актуальними залишаються такі питання забезпечення коригувального зворотного зв'язку під час вивчення іноземної мови (IM) у закладах вищої освіти (ЗВО): які є ефективні способи його здійснення та як правильно виправляти помилки студентів під час усного та письмового мовлення.

Аналіз останніх досліджень і публікацій. Проблема забезпечення зворотного зв'язку є не лише педагогічною, а й психологічною, оскільки стосується міжособистісного спілкування та взаємної діяльнос- ті. Для соціальної психології це і зараз досить нова галузь досліджень. Гордієнко та Копець (2008) стверджують: «Зворотний зв’язок перетворюється в одну iз таємничих проблем соціальної психології. Попри достатню кількість досліджень розуміння цього аспекту проблема знову і знову набирає вигляду такої, над якою можна починати працювати спочатку. Це свідчить про їі складність. Навіть найпростіше дослідження часто є надзвичайно трудомістким. Коло дослідників цієї проблеми доволі невелике. Можна сказати, що психологи відступають перед нею: хоча iii значення постійно декларується, проте конкретних досліджень мало. Сьогодні проблема перебуває у стані консервації рівня 80-х рр., коли проблема була задекларована і проводились перші експериментальні дослідження...» (с. 49).

Щодо педагогічних пошуків питання зворотного зв'язку впродовж тривалого часу розглядалося здебільшого у працях закордонних учених. Огляд цих праць свідчить про те, що дослідники вивчали класифікацію видів зворотного зв'язку (Berg, Dochy, Huth, Kielt, Lockhart, Moerkerke, Murray, Narciss, Sluijsmans). Ця проблема є актуальною і в працях сучасних учених. Так, вітчизняні науковці-філологи пропонують різноманітну типологію зворотного зв'язку і розглядають його в різних контекстах: викладач-студент (Божук, \& Малик, 2010; Вінниченко, 2012; Куценко, 2010; Клязника, 2014), в усному чи писемному мовленні (Куровська, 2004; Назола, 2013), у дистанційній формі навчання (Муліна, 2013). Зарубіжні вчені особливу увагу приділяють вивченню питання обізнаності студентів про види ефективного зворотного зв'язку, їхнього усвідомлення важливості його використання, а також досліджують здійснення зворотного зв'язку між студентами (Hall, 2017; Chen, Lin, \& Jian, 2016; Kruidering-Hall, O’Sullivan, \& Chou, 2009; Mak, 2019; Rossiter, 2016). Однак попри значну кількість публікацій з проблеми, що розглядається, окремої уваги потребує дослідження механізму здійснення коригувального зворотного зв'язку, який у різних наукових працях має різні назви: «корегуючий», «коригуючий», «коригувальний», «corrective feedback».

Мета статті - визначити поняття «коригувальний зворотний зв'язок» та дослідити умови забезпечення ефективного коригувального зворотного зв'язку між викладачем та студентом у процесі вивчення IM у 3ВО за допомогою вивчення його функцій, видів, етапів, шляхів та способів здійснення.

Виклад основного матеріалу дослідження. Зворотний зв'язок відіграє важливу роль у процесах засвоєння IM. Функція зворотного зв'язку є основною 
функцією контролю (особливо поточного), яка забезпечує керування процесом навчання IM (Клязника, 2014). Проте зворотний зв'язок не є лише показником знань студентів (Mak, 2019). Зворотний зв'язок діє у двох напрямках: на викладача і на студента. Зворотний зв’язок, що діє в напрямку до викладача, дає йому інформацію про рівень успішності студентів. Викладач аналізує цю інформацію щодо наявності недоліків, проводить моніторинг відхилень у мовленнєвій діяльності студентів, виявляє ступінь відповідності обраної стратегії і тактики навчання реальним потребам. Це дає змогу своєчасно оцінити методичну ситуацію і внести необхідні коригувальні зміни щодо добору прийомів, способів і методів навчання, добору вправ, визначення режиму і тривалості їх виконання, послідовності організації усієї навчальної роботи зі студентами. Зворотний зв'язок у напрямку до студентів дає їм інформацію про результат їхньої навчальної діяльності з оволодіння іншомовними навичками та вміннями (Клязника, 2014). У такий спосіб студенти інформуються про сильні та слабкі сторони в процесі навчання (Mak, 2019).

Шляхи здійснення зворотного зв'язку різноманітні.

Традиційний шлях полягає в заповненні роздрукованих копій та подальшій перевірці роботи студента. Зазвичай такий спосіб є повільним, тому його слід уникати в тому випадку, коли потрібний миттєвий зворотний зв'язок.

Студенти можуть ставити питання викладачеві, наприклад після пояснення граматичного матеріалу або для уточнення правильної вимови лексичних одиниць під час практичних занять та отримувати миттєвий зворотний зв'язок.

Викладач може дати студентові домашні завдання на розв'язання проблемних ситуацій або виконання тестових завдань.

До студенів, які активні на практичних заняттях та виконують самостійні роботи, викладач має завжди добирати завдання для забезпечення зворотного зв'язку. Таким способом підтримується активність та зацікавленість студента.

Найпростіший шлях для отримання зворотного зв'язку забезпечується за допомогою запам'ятовування основних понять та самоперевірку знань. Педагог має бути впевнений у тому, що основні поняття викладено стисло та зрозуміло.

Комп’ютерні програми здатні перевіряти рівень знань студентів, наприклад, використовуючи контрольні запитання.

Викладач вибирає механізми забезпечення зворотного зв’язку з урахуванням реакції студентів. Дуже важливо допомогти студентам зрозуміти їхню роль у виборі цих шляхів, вміти розпізнавати та сприяти їх здійсненню (Rossiter, 2016).

Для забезпечення ефективності зворотного зв'язку слід дотримуватись послідовності в його організації. На першому етапі відбувається оцінка успішності, ступеня засвоєння матеріалу студентом та постановка цілей; на другому етапі - оцінювання, самооцінювання, взаємооцінювання; на третьому етапі - моніторинг студентами досягнень, рефлексія (Mak, 2019). Ефективний зворотний зв'язок має три аспекти: структуру (цілі, місце проведення, час, орієнтація студента в змісті матеріалу); зміст (конструктивний, диференційований); формат (усний, письмовий, графічний, відеопрезентація) (KruideringHall, O’Sullivan, \& Chou, 2009).

Оскільки «коригувальний зворотний зв'язок, відомий як виправлення помилок або корекція граматики, є основним засобом для викладача в роботі над помилками студентів» (Chen, Lin, \& Jian, 2016, p.85), розрізняють усний та письмовий коригувальний зворотний зв'язок між викладачем та студентом у процесі вивчення IM.

Відомі різні види усного коригувального зворотного зв'язку, а саме: експліцитний (прямий), металінгвістичний та імпліцитний (непрямий) зворотний зв'язок, який поділяється на такі підвиди: перефразування висловлення, запит уточнення, прагнення отримати правильну відповідь й повторення з наголосом на помилці (повтори) (Назола, 2013; Tedick, \& Gortari, 1998).

Назола (2013) переконана, що найкращим є поєднання різних типів усного коригувального зворотного зв'язку, що мають застосовуватися залежно від рівня підготовки студентів, виду навчальної діяльності, преференцій студентів, стилів учіння та багатьох інших чинників.

Експліцитний (прямий) усний зворотний зв'язок характеризується голосною й чіткою вказівкою на наявність помилки й наданням переформулювання іноземною мовою. Експліцитний зворотний зв'язок більш ефективний стосовно спонукання студента до правильного застосування проблемної структури як під час занять, так і в подальшому тестуванні.

Стратегія металінгвістичного усного зворотного зв'язку полягає в отриманні студентами лінгвістичних ключів для самостійного виправлення помилок. Цей вид зворотного зв'язку може застосовуватися трьома способами, як-от: металінгвістичні коментаpi, металінгвістична інформація, металінгвістичні запитання. Найменш інформативними вважають коментарі, що лише позначають факт виникнення помилки. Металінгвістична інформація не лише вказує на наявність чи місце помилки, але й пропо- 
нує певну метамову, що побічно вказує на 110 природу. Металінгвістичні запитання привертають увагу до природи помилки, але при цьому спонукають студентів до самостійного відтворення цієї інформації. Недоліком металінгвістичного зворотного зв'язку є те, що він стримує плавність висловлювання. Іноді його відносять до експліцитного зворотного зв'язку.

Запит уточнення застосовується тоді, коли викладач упевнений, що студент володіє належними лінгвістичними здібностями, і спонукає студента до переформулювання свого висловлення. На відміну від експліцитного коригування помилки чи перефразування, запит уточнення є більш надійним засобом для відтворення студентом виправленого формулювання.

Найбільшої уваги заслуговує перефразування, оскільки воно найчастіше застосовується в навчальній практиці, хоча часто $є$ причиною позитивних і негативних реакцій. Його частіше застосовують відносно граматичних і фонетичних помилок. Перефразування надають студентам правильні форми іноземної мови, причому в такому контексті, в якому визначаються зв'язки між формою і змістом. До того ж, перефразування не порушують плин спілкування, що сприяє засвоєнню мовного та мовленнєвого матеріалу. Коригувальний зворотний зв'язок сприятиме сприйняттю студентом коригувальної дії викладача під час обговорення форми, коли студентів спонукають до самостійного виправлення помилок і надають ключі, що підказують студентам про необхідність коригування неправильно сформульованих висловлень.

Перефразування $\epsilon$ найпоширенішим способом коригування усних (граматичних і фонетичних) помилок, хоча студенти 3 низьким рівнем підготовки не завжди або не в повному обсязі його помічають. Тому викладач має узгоджувати перефразування висловлень $з$ рівнем мовної компетентності студентів, поєднувати його з іншими видами зворотного зв'язку. Причинами цього можуть бути такі чинники: обмеженість оперативної пам'яті студентів, ознайомлення 3 новим мовним матеріалом, численні виправлення, складні зміни в перефразуванні, низький рівень мовної підготовки студентів, а також наявність нових граматичних структур, ще не опанованими студентами. Тому перефразування доцільніше застосовувати під час роботи зі студентами, які володіють вищим рівнем мовної підготовки.

Прагнення отримати правильну відповідь від студента - спонукання його до самостійного виправлення помилки. Ця стратегія може застосовуватися в одному із трьох варіантів. За першого варіанта викладач просить студента переформулювати помилкове висловлення, за другого варіанта викладач ставить відкриті запитання. Останній варіант, що є найменш спонукальним, а отже, найбільш імпліцитним, полягає в застосуванні пауз мовчання з метою надання можливості студентові самому закінчити фразу. Цей вид коригувального зворотного зв'язку зазвичай не застосовується паралельно з іншими типами зворотного зв'язку.

Повторення полягає в повторенні викладачем некоректно сформульованої частини висловлення, зазвичай $з$ наголосом на помилці (Назола, 2013).

Коригувальний зворотний зв'язок іноді вважають одним із видів негативного зворотного зв'язку. Це пов'язують 3 тим, що коли студент робить помилку, викладач насамперед має визначити, яка це помилка, чи варто її виправляти, а також, хто має її виправляти. Водночас «для покращення успішності він має бути позитивним та давати студентам задоволення» (Hall, 2017, p.18).

Назола (2013) вважає, що коли йдеться про активізацію плавності мовлення, то краще відкласти коригування до закінчення виконання вправ на швидкість мовлення, після чого зробити аналіз завдання шляхом застосування однієї зі слушних стратегій зворотного зв'язку. Однак бажано негайно виправляти помилки під час виконання вправ, спрямованих на відпрацювання точності мовлення.

Письмовий коригувальний зв'язок пов'язаний 3 підходом до виправлення помилок студента в письмовій роботі, який має бути добре збалансований та вибірковий до різних типів помилок. Відомі різні підходи щодо його видів. Одні дослідники розрізняють прямий зворотний зв'язок, коли викладач сам виправляє помилку і надписує правильну відповідь, та непрямий зворотний зв'язок, до якого належать кодування помилок (Spelling - SP, Grammar - GR тощо.) та підкреслення помилки, для того, щоб студент виправив її самостійно (Куровська, 2004). Дослідники Chen, Lin та Jian (2016) схиляються до думки про те, що прямий коригувальний зворотний зв'язок поділяється на два різновиди: помилки виправляються викладачем особисто або із застосуванням металінгвістичної інформації, а до непрямого коригувального зв'язку належить лише виправлення студентів, що змушує їх мислити самостійно.

Ефективний вплив на формування й удосконалення навичок і вмінь писемного мовлення відіграють виявлення та виправлення помилок у співпраці зі студентом у поєднанні з такими видами роботи: обговорення помилок у групі студентів та індивідуально, перевірка й повторне написання письмової роботи після отримання зауважень викладача, мінізаняття 3 певних проблемних питань та ведення обліку помилок з метою розвитку відповідних навичок та 
вмінь студента. Непряме виявлення помилки змушує студента аналізувати іiі, глибше вивчати певне граматичне явище і в процесі такої роботи вдосконалювати свої навички та вміння редагування тексту, що зумовлює появу кращих, довготривалих успіхів у навчанні писемного мовлення.

Щодо партнерського редагування помилок (peerediting) точаться суперечки. Однак відомо, що помилки в чужій роботі часом легше виявити, ніж у власній. Залучення студентів до такої праці здебільшого добре мотивує розвиток їхніх умінь редагувати. У методиці навчання IM запропонований чітко структурований підконтрольний триетапний процес, протягом якого студенти спочатку вивчають помилки в готових текстах, потім редагують роботи один одного і тільки після цього зосереджуються на редагуванні своїх робіт. Однак викладачеві необхідно виробити власну стратегію зворотного зв'язку в ставленні до студентських помилок на письмі (Куровська, 2004).

Сьогодення вимагає забезпечення зворотного зв'язку не лише під час аудиторних занять, а й під час дистанційного навчання. У зв'язку із запровадженням карантину на всій території України для студентів освітній процес було організовано шляхом використання технологій дистанційного навчання.

Суть зворотного зв'язку полягає в тому, що в міжособистісному спілкуванні під час аудиторних занять процес обміну інформацією характеризується безпосередністю, емоційністю, а в дистанційному спілкуванні обмін інформацією відбувається опосередковано, віртуально: викладач впливає на такі природні людські інстинкти, як конкуренція, самовираження, альтруїзм, статусність, розвиває мотиваційні установки у студентів (Филипська, 2020).

Коригувальний зворотний зв'язок під час дистанційного навчання IM $€$ не просто інформуванням студента про правильність/неправильність виконання завдання, виставлення оцінки, балів тощо. Він, скоріше за все, має містити коментар із аналізом помилок, рецензію на виконане завдання для того, щоб допомогти студентові уникнути повторення недоліків у роботі, у виконанні наступних завдань (Муліна, 2013). Його можна рекомендувати при виконанні завдань на формування/удосконалення лексичних та граматичних навичок. Щодо докладного та персоніфікованого позитивного зворотного зв'язку на відкриті завдання, то він дуже позитивно впливає на мотивацію та активність діяльності студентів в умовах дистанційного навчання. Негативний зворотний зв'язок надає студенту інформацію про хибність відповіді. При неправильній відповіді правильний варіант не надається. Підказками студенту можуть бути, наприклад, покликання на відповідні розділи граматичного довідника, допоміжну інформацію, пов’язані з темою Інтернет-сайтів тощо (Филипська, 2020).

Дистанційне навчання сьогодні стало додатковою формою навчання паралельно $з$ денною формою навчання, а тому можна запропонувати проведення самостійних поточних, тематичних контрольних робіт, викладення додаткових навчальних посібників, підручників, словників на дистанційній платформі. При цьому, дистанційне навчання, маючи об'єктивні переваги - гнучкість, відкритість, інтерактивність, індивідуалізація, є економічно вигідним для закладів освіти.

Результати дослідження. Отже, коригувальний зворотний зв'язок - це спосіб корекції помилок студента на етапі контролю знань, навичок та вмінь 3 метою отримання інформації про успішність виконаного завдання та ефективність використаної викладачем методики навчання IM. Він є невід’ємною складником методологічної стратегії процесу навчання іноземної мови у ЗВО.

Підсумовуючи все зазначене вище, зазначимо, що на ефективність зворотного зв'язку впливають такі умови:

- обізнаність викладача щодо видів та способів його здійснення;

- дотримання структури;

- регулярність використання;

- зв’язок з метою оцінювання та критеріями;

- зрозумілість для студента;

- чіткий зв'язок з наступними завданнями, сфокусований передусім на навчальних цілях, а потім - на оцінюванні;

- позитивний вплив на студента;

- здійснення корекції помилок в письмовому мовленні у співпраці зі студентом;

- використання перефразування в усному мовленні для студентів 3 достатнім і високим рівнем володіння IM та поєднання перефразування висловлювання з іншими видами коригувального зв'язку для студентів з середнім рівнем підготовки;

- негайне виправлення фонетичних помилок під час формування та автоматизації вимовних навичок;

- наявність коментарів до виконаних завдань у дистанційній формі навчання;

- деталізованість та індивідуальний підхід.

Перспективи подальших наукових розвідок мають бути спрямовані на науково обгрунтований аналіз та добір ефективних прийомів, методів та засобів здійснення коригувального зворотного зв'язку на різних етапах практичного заняття з IM, у різних формах та видах роботи, з використанням інноваційних технологій навчання, які викладач IM зможе використовувати у практичній діяльності. 


\section{СПИСОК ПОСИЛАНЬ}

Божук, Т., \& Малик, Л. (2010). Роль зворотного зв'язку в навчальному процесі: досвід застосування методів «Три конверти» та анкетування. Молодь і ринок, (7-8), 94-98. Взято з https:// irbis-nbuv.gov.ua.

Вінниченко, Т. О. (2012). Зворотний зв'язок між студентом і викладачем як ефективний засіб аудиторної роботи, Аудиторна робота викладача і студента: досвід і напрями вдосконалення, науково-методична конфреренція, 1, Київ: КНЕУ. Взято 3 https://ir.kneu.edu.ua/handle/2010/11591.

Клязника, В. М. (2014). Методика забезпечення поточного контролю знань на заняттях з англійської мови: Вісник Житомирського державного університету. Педагогічні науки, 4 (76), 109-112.

Копець, Л. В., \& Гордієнко, В. І. (2008). Зворотний зв'язок у процесах спілкування: оновлення концептуальних підходів та методів дослідження: Наукові записки НаУКМА. Педагогічні, психологічні науки та соціальна робота, (84), 49-54.

Куровська, О. В. (2004). Забезпечення зворотного зв'язку в розвитку навичок письма (на матеріалі англійської мови): Науков записки. Філологічні науки, 34, 59-63.

Куценко, Є. М. (2010). Зворотній зв'язок між викладачем та студентом у процесі навчання, Забезпечення відкритості, прозорості та об'єктивності оцінювання якості навчальної роботи студентів: досвід, проблеми, перспективи розвитку, науковометодична конференція, 2, Київ: КНЕУ. Взято з https://ir.kneu. edu.ua/handle/2010/10811?show=full.

Муліна, Н. І. (2013). Організація ефективного зворотного зв'язку в дистанційному навчанні іноземних мов: Гуманітарний вісник ДВНЗ Переяслав-Хмельницький державний педагогічний університет імені Григорія Сковороди, 31(1), 609-616.

Назола, О.В. (2013). Роль усного коригувального зв'язку у навчанні студентів іноземної мови: Педагогіка, 139-147.

Филипська, В. І. (2020). Створення психологічного комфрорту через зворотний зв'язок у системі дистанційного навчання іноземним мовам, V Міжнародна науково-практична конфреренція, Підготовка поліцейських в умовах реформування системи МВС України. Харків, Україна: ХНУВС.

Chen J., Lin J., \& Jian L. (2016). Corrective feedback in SLA: Theoretical relevance and empirical research English language teaching, 9 (11), 85-94. doi: 10.5539/elt.v9n11p85.

Hall, Dara M. (2017). The power of feedback: an indicator of mentor effectiveness during student teaching. (Doctoral dissertation). James Madison University, Yarrissonburg, Virginia, the USA. Retrieved from https://commons.lib.jmu.edu/diss201019/141.

Kruidering-Hall, M, O'Sullivan, PS, \& Chou, CL. (2009). Teaching feedback to first-year medical students: long-term skill retention and accuracy of student self-assessment: Journal of general internal medicine, 24 (6), 721-726. Retrieved from https://link.springer.com/ content/pdf/10.1007\%2Fs11606-009-0983-z.pdf .

Mak, P. (2019). From traditional to alternative feedback: What do L2 elementary students think? Int J Appl Linguist, 29, 109-129. Retrieved from https://onlinelibrary.wiley.com/doi/abs/10.1111/ ijal.12250.

Rossiter, J.A. (2016). Using an understanding of feedback processes to improve student learning, IFAC-PapersOnLine, 11th IFAC Symposium on Advances in Control Education, 49 (6). Bratislava, SLOVAKIA. doi.org/10.1016/j.ifacol.2016.07.153.

Tedick, D., \& Gortari, B. (1998). Research on error correction and implications for classroom teaching. The ACIE Newsletter, 1 (3). Retrieved from https: //www.carla.umn.edu.

\section{REFERENCES}

Bozhuk, T., \& Malyk, L. (2010). Rol zvorotnoho zv'iazku v navchalnomu protsesi: dosvid zastosuvannia metodiv «Try konverty» ta anketuvannia. Molod i rynok, (7-8), 94-98. Vziato z https://irbisnbuv.gov.ua.

Vinnychenko, T. O. (2012). Zvorotnyy zv'yazok mizh studentom i vykladachem yak efektyvnyy zasib audytornoyi roboty, Audytorna robota vykladacha i studenta: dosvid i napryamy vdoskonalennya, naukovo-metodychna konferentsiya, 1, Kyyiv: KNEU. Vzyato z https://ir.kneu.edu.ua/handle/2010/11591.

Klyaznyka, V. M. (2014). Metodyka zabezpechennya potochnoho kontrolyu znan' na zanyattyakh z anhliys'koyi movy: Visnyk Zhytomyrs'koho derzhavnoho universytetu. Pedahohichni nauky, 4 (76), 109-112.

Kopets, L. V., \& Hordiienko, V. I. (2008). Zvorotnyi zviazok u protsesakh spilkuvannia: onovlennia kontseptualnykh pidkhodiv ta metodiv doslidzhennia: Naukovi zapysky NaUKMA. Pedahohichni, psykholohichni nauky ta sotsialna robota, (84), 49-54.

Kurovska, O. V. (2004). Zabezpechennia zvorotnoho zv'iazku v rozvytku navychok pysma (na materiali anhliiskoi movy): Naukovi zapysky. Filolohichni nauky, 34, 59-63.

Kutsenko, Ye. M. (2010). Zvorotnii zv'iazok mizh vykladachem ta studentom u protsesi navchannia, Zabezpechennia vidkrytosti, prozorosti ta ob'iektyvnosti otsiniuvannia yakosti navchalnoi roboty studentiv: dosvid, problemy, perspektyvy rozvytku, naukovometodychna konferentsiia, 2, Kyiv: KNEU. Vziato z https://ir.kneu. edu.ua/handle/2010/10811?show=full.

Mulina, N. I. (2013). Orhanizatsiia efektyvnoho zvorotnoho zviazku v dystantsiinomu navchanni inozemnykh mov: Humanitarnyi visnyk DVNZ Pereiaslav-Khmelnytskyi derzhavnyi pedahohichnyi universytet imeni Hryhoriia Skovorody, 31(1), 609-616.

Nazola, O. V. (2013). Rol usnoho koryhuvalnoho zv'iazku u navchanni studentiv inozemnoi movy: Pedahohika, 139-147.

Fylypska, V. I. (2020). Stvorennia psykholohichnoho komfortu cherez zvorotnyi zv'iazok u systemi dystantsiinoho navchannia inozemnym movam, V Mizhnarodna naukovo-praktychna konferentsiia, Pidhotovka politseiskykh v umovakh reformuvannia systemy MVS Ukrainy. Kharkiv, Ukraina: KhNUVS.

Chen, J., Lin, J., \& Jian, L. (2016). Corrective feedback in SLA: Theoretical relevance and empirical research English language teaching, 9 (11), 85-94. doi: 10.5539/elt.v9n11p85.

Hall, Dara M. (2017). The power of feedback: an indicator of mentor effectiveness during student teaching. (Doctoral dissertation). James Madison University, Yarrissonburg, Virginia, the USA. Retrieved from https://commons.lib.jmu.edu/diss201019/141.

Kruidering-Hall, M, O'Sullivan, PS, \& Chou, CL. (2009). Teaching feedback to first-year medical students: long-term skill retention and accuracy of student self-assessment: Journal of general internal medicine, 24 (6), 721-726. Retrieved from https://link.springer.com/ content/pdf/10.1007\%2Fs11606-009-0983-z.pdf .

Mak, P. (2019). From traditional to alternative feedback: What do L2 elementary students think? Int J Appl Linguist, 29, 109-129. Retrieved from https://onlinelibrary.wiley.com/doi/abs/10.1111/ ijal.12250.

Rossiter, J.A. (2016). Using an understanding of feedback processes to improve student learning, IFAC-PapersOnLine, 11th IFAC Symposium on Advances in Control Education, 49 (6). Bratislava, SLOVAKIA. doi.org/10.1016/j.ifacol.2016.07.153.

Tedick, D., \& Gortari, B. (1998). Research on error correction and implications for classroom teaching. The ACIE Newsletter, 1 (3). Retrieved from https: //www.carla.umn.edu.

Отримано 02.09.20 